\title{
DEVELOPING A VIRTUAL MUSEUM FOR THE ANCIENT WINE TRADE IN EASTERN MEDITERRANEAN
}

\author{
S. Kazanis ${ }^{\text {a }}$, G. Kontogianni ${ }^{\text {b }}$, R. Chliverou ${ }^{\text {b }}$, A. Georgopoulos ${ }^{\text {b }}$
}

\author{
${ }^{a}$ Department of Mediterranean Studies, Master Course: "Archaeology of the Eastern Mediterranean from Prehistory to Late \\ Antiquity: Greece, Egypt, the Near East” University of the Aegean \\ savvas.kazanis@hotmail.com \\ ${ }^{\mathrm{b}}$ Laboratory of Photogrammetry, School of Rural and Surveying Engineering, National Technical University of Athens - \\ 15780 Zografou Athens, Greece \\ gkondog@central.ntua.gr - regina@survey.ntua.gr -drag@central.ntua.gr
}

\section{KEY WORDS: Virtual Museum; 3D models; amphora; stamped handles; Stoa of Attalos}

\begin{abstract}
:
Digital technologies for representing cultural heritage assets of any size are already maturing. Technological progress has greatly enhanced the art of virtual representation and, as a consequence, it is all the more appealing to the general public and especially to younger generations. The game industry has played a significant role towards this end and has led to the development of edutainment applications. The digital workflow implemented for developing such an application is presented in this paper. A virtual museum has been designed and developed, with the intention to convey the history of trade in the Eastern Mediterranean area, focusing on the Aegean Sea and five productive cities-ports, during a period of more than 500 years. Image based modeling methodology was preferred to ensure accuracy and reliability. The setup in the museum environment, the difficulties encountered and the solutions adopted are discussed, while processing of the images and the production and finishing of the $3 \mathrm{D}$ models are described in detail. The virtual museum and edutainment application, MEDWINET, has been designed and developed with the intention to convey the essential information of the wine production and trade routes in the Eastern Mediterranean basin. The user is able to examine the 3D models of the amphorae, while learning about their production and use for trade during the centuries. The application has been evaluated and the results are also discussed.
\end{abstract}

\section{INTRODUCTION}

Technological progress has greatly enhanced the art of virtual reality and its use is, therefore, becoming more attractive digital applications in the cultural heritage domain to the public and especially to younger generations. Digital technologies for representing cultural heritage assets of any size are already maturing. Museums introduce new technologies in their environment, providing historic information with an interactive educational path to visitors. In this contribution, the development of a virtual museum (MEDWINET) about the Stoa of Attalos has been designed and developed, with the intention to convey the history of trade in the Eastern Mediterranean area, focusing on the Aegean Sea and five wine producing cities-ports, during a period of more than 500 years. A rich collection of commercial amphorae, mainly stamped, from the whole Mediterranean basin are displayed in one of the -temporarily- closed to the public rooms of the Stoa of Attalos. The Stoa is a huge building in the ancient Agora of Athens, reconstructed 60 years age to house the Agora Museum. It is the intention of the archaeologists to expose these amphorae to the public, using a non-traditional and unconventional way of presentation, by developing a fully digital virtual museum. In order to demonstrate the basic principles of this task, five amphorae were carefully chosen to be digitally reconstructed in three dimensions. They are representative specimens of the main wine producing city-states of the area. In addition, four of the displayed stamped amphorae handles were also chosen for enhancing the storytelling. These artefacts were suitably photographed to produce their photorealistic threedimensional models. These produced 3D models were included into the virtual museum and edutainment application, MEDWINET, which has been designed to convey the essential information of the wine production and trade routes in the Eastern Mediterranean basin. It has been developed within Unity 3D personal edition software (Unity 3D, 2017) and includes an interactive introductory educational part and a virtual museum application with historical information about the amphorae and the handles in order to convey knowledge to public.

\section{HISTORIC REFERENCE}

\subsection{Ancient Trade - Stoa of Attalos.}

The presence of pottery in excavations and shipwrecks, is one of the most important testimonies of antiquity, and provide to scholars with answers to questions during archaeological research. Questions concerning the construction and use of objects, everyday life, peoples' relationships, trade, economy and transportation of goods. From the beginning of the development of trade, humanity searched and developed means to transport the products. In antiquity, this mean was the amphora. Amphorae are recognized as one of the important sources of economic information of the Classical and Hellenistic Greece (Foley et al. 2012). The name "amphora" originates from the Greek word "amphiphoreus" or "amphoreus" 1 " (Grace, 1979) a combination of the word "amphi" (on both sides) and "phoreus" (carrier)

${ }^{1}$ Grace (1977) quotes that Homer uses the word "amphora" for the wine jars used by Telemachos, son of Odysseus (Odyssey II, 290, 349, 379) 
referring to a closed shaped jar made of clay with both handles to store and transport goods (Stefanakis, 2012).

Their form developed according to the need for a container large enough to hold large quantities of goods, but small enough to be handled easily by the user (Will, 1977). There is a variety of shapes, but a narrow mouth, two opposite handles and a knob at the bottom (used as a third handle) are the common parts on typical amphorae (Grace, 1979). The invention of a two-handled jar seems to have originated from the Phoenicians and on the coast of later Syria and Palestine, in the contrast of the respective Egyptian invention, which had no handles, before the adoption from Greeks and Egyptians (Grace, 1979). The adaptation of the shape according to the needs of the merchants should be attributed to the Greeks (Grace, 1979), who dominated on the trade of the Mediterranean during the Classical and Hellenistic period. The shape had been streamlining in order to help the user. The neck served as both a holder for an airtight stopper and as a tunnel for pouring out the contents. A rim on the top of the neck aids to control the flow and the knob-toe at the end of the jar helped in the lifting and emptying the contents (Will, 1977). The main part is the body, which aids on the storage of the jar on storage areas and ships. Grace (1979) mentions that the shape was important because in the ships or in the warehouses the amphorae are placed in a way that they support each other.

Amphorae played a major role on the transportation of goods in the Mediterranean filled mainly with wine, but also with oil, herbs, walnuts, olives (Foley et al. 2012). In modern times, this ancient container provides to archaeologists important information about the economy, the market centers of the antiquity and the trade routes. Amphorae have a long association with economic history (Lawall, 1999), as far as they carry economic evidence like stamps and inscriptions, mainly on the top of the handles (Grace, 1979). Moreover, the shape and the stamps identify the city of origin. Chian amphora were stamped with Chian coins, Koan jars carry inscriptions with names of their maker and the eponymous archon (the ruler of the city) (Lawall, 1999). Stamped amphorae exist from the Mycenaean era (bronze age 1600-1100 BC) carrying a) a male name, b) a place name and c) in some occasions the word "wa-na-ka-te-ro" which refers to owner's name (Hooker, 1980). The technique of sealing the handles continued for centuries. Each Greek city state or production area could be identified by its own sealing system and motif. The Rhodian amphorae carry the symbol of the god Helios or the symbol of the city, i.e. the rose, the Chian amphorae are sealed with a Chian coin in the form of the sphinx and the shape of the amphora. With this logic, Cnidus uses the beef symbol and Kos the crab. Other productive cities follow the same technique. The city of Mende distinguished its jars by stamps showing Mendean coins. Thasos island stamps amphorae with the names of magistrates and producers. Hence, stamped handles play a significant role on archaeological, economic and social research (Will, 1977).

The Agora Museum of Athens is located at the center of the Ancient Greek Agora and is housed on the restored Stoa of Attalos. Grace (1979) mentions that during the excavations in the Agora of Athens more than 40 thousand handles have been found, while in Alexandria more than 90 thousand handles were excavated. On this museum almost 15 thousand stamped handles are stored and exhibited at the moment (Mauzy, 2006).

Stoa " $\Sigma \tau$ oó" in Greek, "Porticus" in Latin (Hölscher, 2002) was a key architectural element of the urban web of an ancient Greek or Roman city. It is a rectangular building with a solid wall in the back, and a row of columns along the front. Hölscher (2002) states that stoa is an independent and autonomous building, but can be united with other stoas and buildings to create a larger architectural complex. The shape of the building was intended to provide shelter to a large number of citizens (Thompson, 1959) from the elements of nature (Glowanski, 2004), to the creation of spaces that served as shops. It can be said that they functioned like modern closed markets.

The construction of the Stoa of Attalos was donated by and named after King Attalos II of Pergamon, who ruled between 159 and 138 BC (Dakari, 1996). The Stoa had a length of 116 meters and a width of 20 meters, it had two floors and inside there was a double colonnade and 21 shops on each level. The height of each pillar was 5 meters for the first level and 3 meters for the second. The shops were all 5 by 5 meters. At the first level, there were 45 pillars of Doric and 22 of Ionic type. While on the second level there were pillars of Pergamon or Egyptian order. Staircases on both sides of the building led to the top level. The reconstruction was carried out in the years 1953-1956, with donations from Greek and American citizens, mainly from John. D. Rockefeller (Gawlinski, 2014) under the supervision of the Department of Restorations of the Greek Ministry of Education and the American School of Classical Studies in Athens (Thompson 1955; Thompson 1957). Today the museum of the Agora stores almost 180 thousand objects, and after the last renovation in 2012, it presents the history of the private and public life of the Athenians.

At the first level, in one of the -temporarily-closed to the public shops, the history of the Mediterranean trade is preserved from the Classic era until the Byzantine times through the display of amphorae and fragments of mainly stamped handles. Amphorae from different places of Mediterranean, even from Spain and Italy are displayed on the side walls of the room on three wooden shelves by area of origin and chronology. In the middle of the room in a showcase fragments of stamped handles with the same way of exhbition, categorized by area of origin and chronology are displayed (Fig. 1).

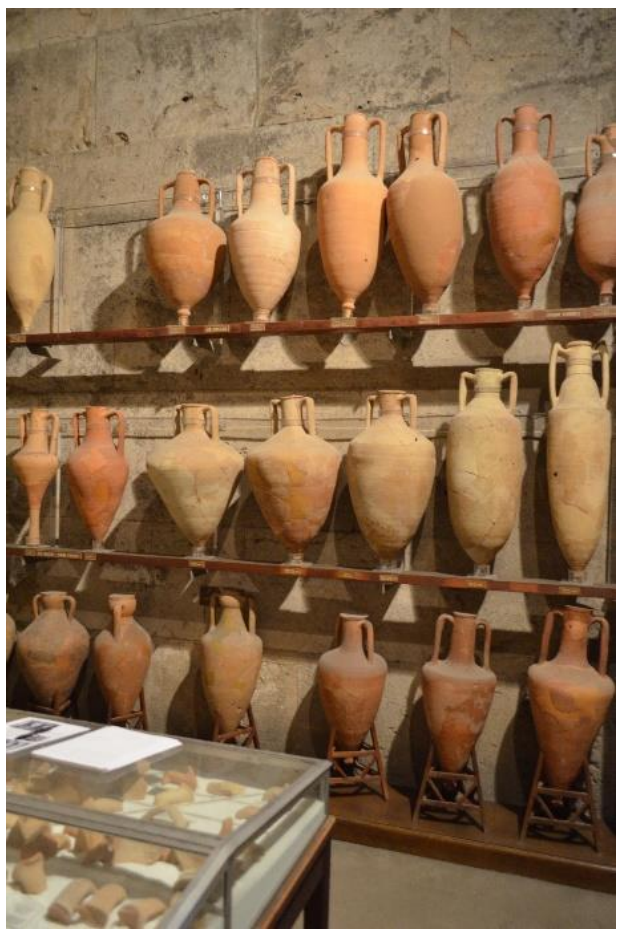

Figure 1: The amphorae shop in the Agora museum 


\subsection{Amphorae - Stamped Handles}

This study focuses on two objectives. The first one is the creation of 3D models of a selection of amphorae and stamped handles from the Classic and Hellenistic period, by examining conserved amphorae from Athens and 4 ancient productive cities (Chios, Rhodes, Kos, Knidos) and also fragments of stamped handles. The second objective is the creation of a virtual museum for the "shop" of Stoa of Attalos, where amphorae are stored.

The amphorae used for this study were selected based on the chronological coverage of the different shapes and seals on the handles, starting from the 5th century BC up to the 1st century BC. The objects selected were a) an Athenian amphora (575-535 $\mathrm{BC}), \mathrm{b})$ a Chian amphora (500 BC), c) a Rhodian amphora (end of 3rd c. BC), d) a Knidian amphora (188-167 BC) and e) a Koan (1st century BC) (Fig. 2). In addition, four fragments of stamped handles with the same chronologies from Chios, Rhodes, Knidos and Kos (Fig. 3) were also selected.
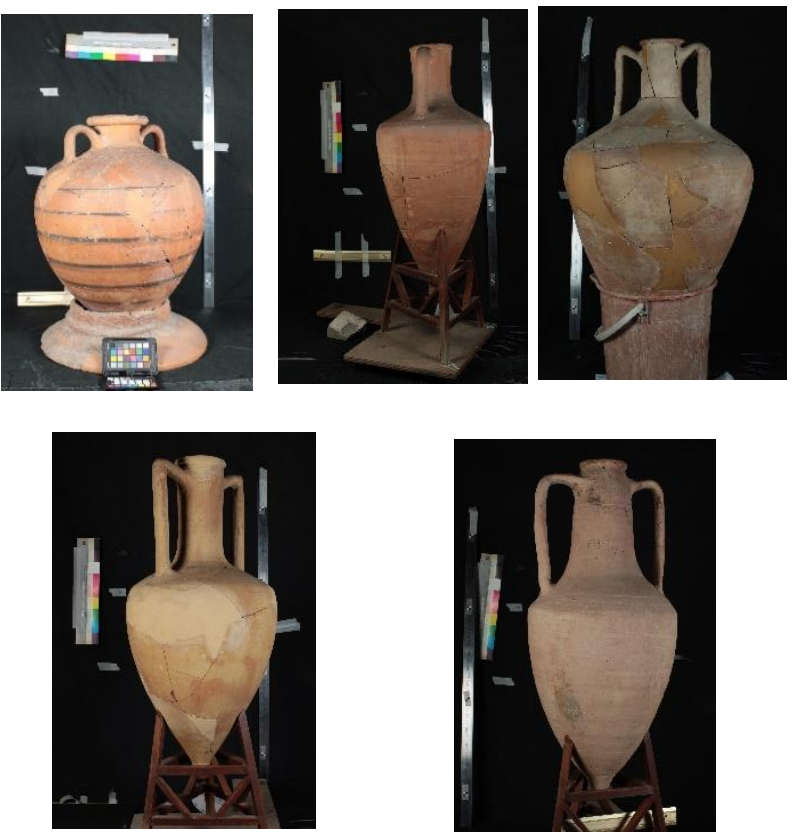

Figure 2. 3D models of amphorae from Athens, Chios, Kos, Rhodes and Knidos (from top left )
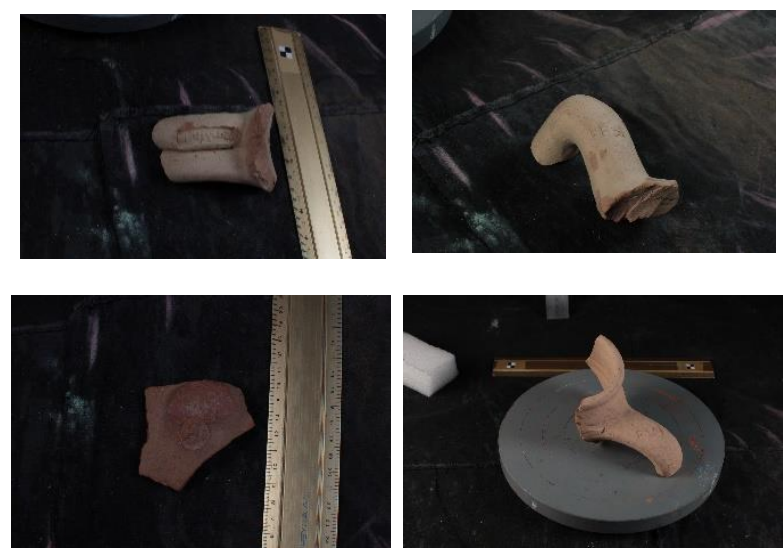

Figure 3. Stamped handles from Kos, Rhodes, Chios and Knidos (from top left)
All the amphorae have stamped handles, except the Athenian one. The amphorae of Chios stand out from the colour of the clay and their shape, which acquires different forms as it is inextricably linked to the economic conditions per period. The Chian amphora has a stamp on the basement of one handle presenting a sphinx and an amphora. The Rhodian amphora was stamped on both handles with rectangular seals bearing the name of the famous lord, the name of the manufacturer, and the name of the month of production. ( $\Theta \mathrm{E} \Sigma \mathrm{T} \Omega \mathrm{P}, \triangle \mathrm{IOY}, \Pi \mathrm{HANAMO} \Sigma$ respectively). While the fragment has a circular stamp with the symbol "rose" (Whitbread, 1995) and the inscription: "PANAMOS" (month) and the name of "API $\Sigma T \Omega N \Delta A \Sigma$ " (Rhodian Lord).

The Knidian handle has a stamp with the name

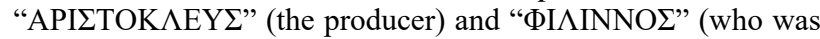
the ruler of the city). The fragment was stamped with the name "API $\Sigma T O K \Lambda E Y \Sigma$ " framing a "bucranium". Finally, a Koan amphora with the inscription "A $\Sigma \mathrm{K} \Lambda \mathrm{H}$ " was selected and the corresponding handle fragment has a rectangular stamp with the symbol of "crab" (Grace, 1979) and illegible name (probably SIA-Y-A). According to Whitbread (1995), the combination of symbol and name on stamps was common practice.

\section{METHODOLOGY}

In this section, the data collection is presented and their integration is explained in order to create the 3D models of the artefacts.

\subsection{Data Collection}

The artefacts were photographed with a Canon EOS 1Ds Mark III (DSLR-AF-AE) camera which employs a CMOS, full frame sensor $36 \times 24 \mathrm{~mm}$ in size with aspect ratio 3:2. Furthermore, a Canon, fixed focal length, EF $50 \mathrm{~mm} \mathrm{~L} \mathrm{USM} \mathrm{lens,} \mathrm{was} \mathrm{used}$ providing an f/1.2 maximum aperture. The sensor's resolution was $21 \mathrm{MP}$ with sel/pixel size 6.4 microns. Shots were taken using two formats: Raw for high resolution and JPEG (Large) for fast processing.

The scene was illuminated by two Bowens Duo Lite studio flashlights with their control panel (Bowens lights, 2017) and also two $40 \times 50 \mathrm{~cm}$ soft boxes were used in order to reduce the harsh shadows. During the flash metering and while the ISO sensitivity was set at 100 , the flash synchronization shutter speed of $1 / 60$ was selected in combination with the smallest aperture value of $f / 16$, in order to achieve the largest depth of field. This was achieved thanks to the high luminance provided from the above-mentioned flashlights. These flashlights were placed about 1 meter away from the objects at 45 degrees, right and left, operating at their maximum luminance.

The use of a XRite ${ }^{\circledR}$ colour card was considered necessary in order to achieve high radiometric accuracy. In addition, a black background was used to facilitate the masking process of the images at the next stage that involves the creation of the $3 \mathrm{D}$ model.

The camera was stationary, mounted on a tripod (Photo Tripod Manfrotto 804RC2), while the artefacts were rotated on a turntable at predetermined positions of approximately 10 degrees so as to be recorded at a full 360-degree rotation. The rotation of the objects was performed exclusively by the responsible conservator and the archaeologist for safety reasons. 


\subsection{D models creation}

The 3D models of the objects were created with Agisoft Photoscan software (Agisoft Photoscan, 2017). After evaluating and archiving the captured photos, each item was individually edited on chunks, following the automated software steps (Fig. 4 \& Fig. 5).

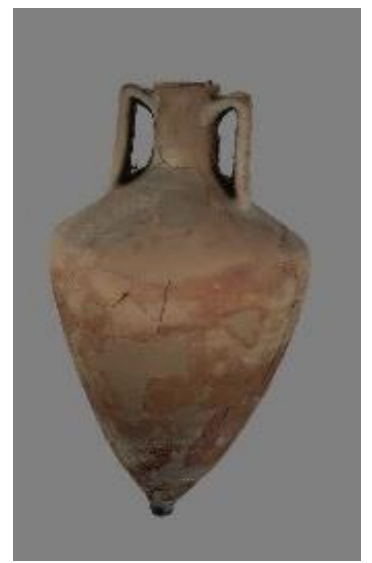

Figure 4. 3D model of the amphora from Kos

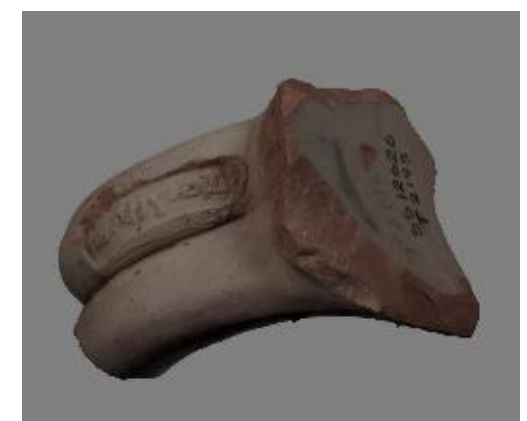

Figure 5. 3D model of the handle from Kos

After the creation of the 3D models, discrepancies between real and virtual objects were observed. In the amphorae models an ellipsoidal "shadow" appeared in the lower part of the body. The "shadow" was caused during the stage of rendering of the texture and colouring (Fig. 6). The software by referring to given pictures, copied to model the shadow of the wooden stand used for the fixation of the amphorae in the shooting phase. In order to solve those problems, it was decided to process the photos from the beginning, but with the implementation of masks in the photos, blocking as much as possible the shade from the wooden base.

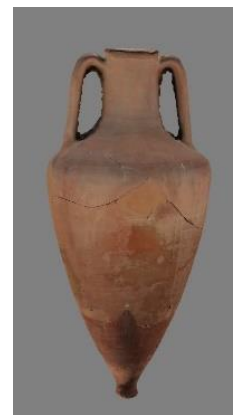

Figure 6. 3D model of Chian amphora

A similar issue occurred in the creation of Koan amphora. Due to the weight and the size of this particular amphora, a bucket was used as support base. During the processing of the 3D Model a color stripe appeared on the periphery of the central part of the amphora (Fig. 7). The solution was, as above, the introduction of masks on the photos by excluding the problematic area and unite chunks with pictures from a different angle without the bucket.

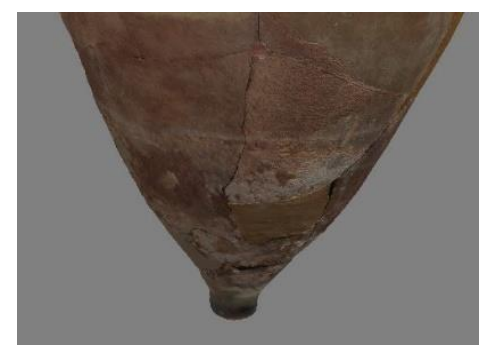

Figure 7. 3D model of Koan amphora

Moreover, on the handle of Chios it was observed that due to its flat and narrow shape it was not possible to use a satisfactory number of markers on the processing parts resulting in the final product exhibiting slight imperfections relative to the actual object (Fig. 8). This problem could easily be solved by taking photos in greater detail in the narrow sections of the object.

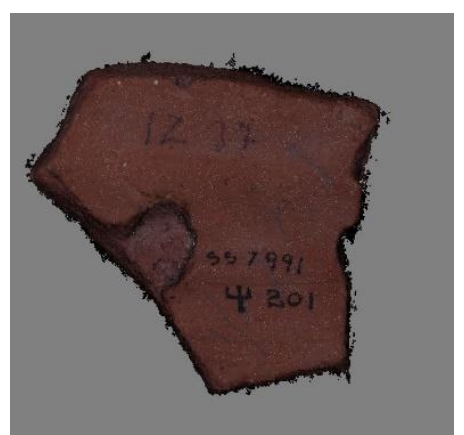

Figure 8. 3D model of the handle from Chios

Another issue occurred during the processing of photographs of the amphora of Cnidus, where alteration in part of the central piece of the 3D model was observed. This alteration lies in the incorrect placement of a marker during the process to unite the upper part and the main amphora's body (Fig. 9). This problem was solved by simply changing the position of the markers.

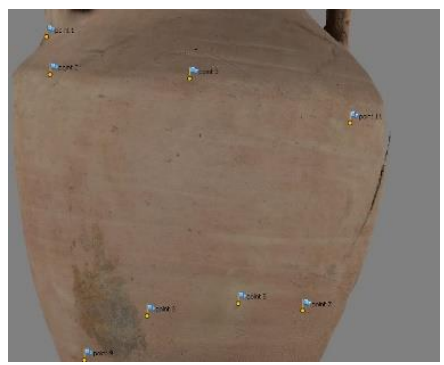

Figure 9.3D model of the Knidean amphora

\section{MEDWINET APPLICATION DEVELOPMENT}

\subsection{Virtual Museum applications}

Virtual museums are spreading in recent years and many applications have been developed using game technologies (Lepouras \& Vassilakis, 2004). These applications provide an ideal means for the digital representation of cultural heritage sites (El- Hakim et al. 2006) in order to entertain and educate visitors 
and also examine all the technologies and tools used in the museum (Hall et al. 2001; Sylaiou at al. 2009).

A web-based virtual application is the Synthesis virtual museum which relies on and exploits the rich content of internal and external web cultural resources in order to encourage players to create their own exhibition with the use of cross-platform gaming technologies (Kiourt et al. 2016). An upgrade of this application is the DynaMus (DynaMus, 2017) application (Kiourt et al. 2016). The historic town "Alt-Segeberger Bürgerhaus" was converted to a museum and a virtual museum was developed (Kersten et al. 2017). The application offers two options for the visitors for exploring the museum without travelling to the city Bad Segeberg, Schleswig-Holstein in Germany. The first option is an interactive computer based tour in order for the visitors to explore the exhibitions and collect information. The second option is to immerse into the virtual reality in 3D with HTC Vive Virtual Reality System. Another virtual museum application utilises 3D models of exhibits located in the Stoa of Attalos museum created with image based reconstruction methods. The visitor is able to manipulate and rotate the exhibits and learn information about them (Skamantzari \& Georgopoulos 2016). The Tech virtual museum by Second Life (Tech virtual museum) give the chance to users to virtually build and display their own collection. Two kinds of museums are offered: the virtual versions of real life museums and museums which were completely designed and conceived for Second Life. A virtual museum that does not exist in reality is the Valentino Garavani Virtual Museum (Valentino Garavani). In this application, the visitor can freely navigate, explore and interact with the exhibits. Finally, in the Acropolis museum website (Acropolis Museum) a variety of online applications, educational programs and serious games are offered to the visitor. All these applications are quite interactive and especially the virtual visit "Athena the Goddess of Acropolis" in which the visitor navigates in the museum, teleports to points of interest, interacts, learns and manipulates the exhibits.

\subsection{MEDWINET Application}

The MEDWINET application was developed in Unity 3D personal edition software (Unity 3D). The application consists of two parts. In the first part the user is presented with a map of the Aegean Sea with instructions about how he may extract information about the places of interest. Emphasis is given in the four amphorae production centres and was realized with the use of an info button colorized with red colour (Fig. 10).

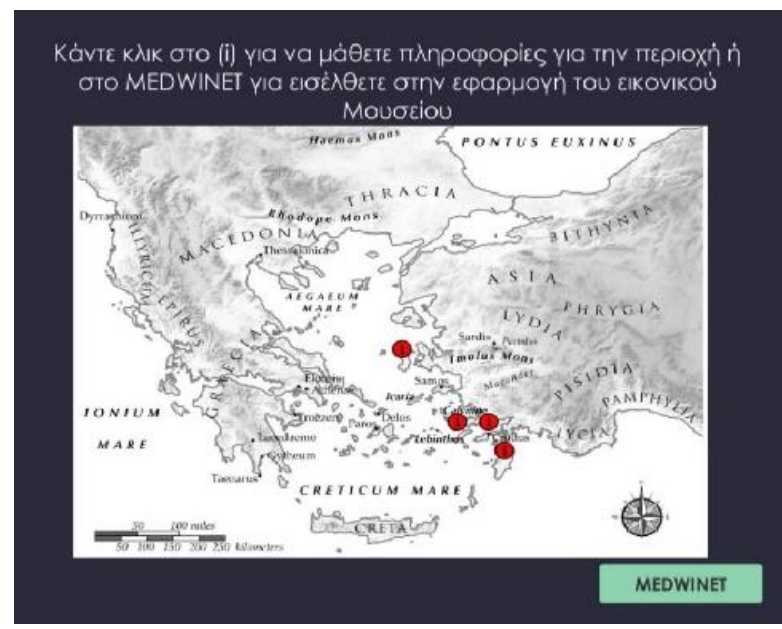

Figure 10. Map of the Aegean Sea
When the player clicks on the info button he/she is able to read information about the place of the amphorae production and the sea routes (Fig 11).

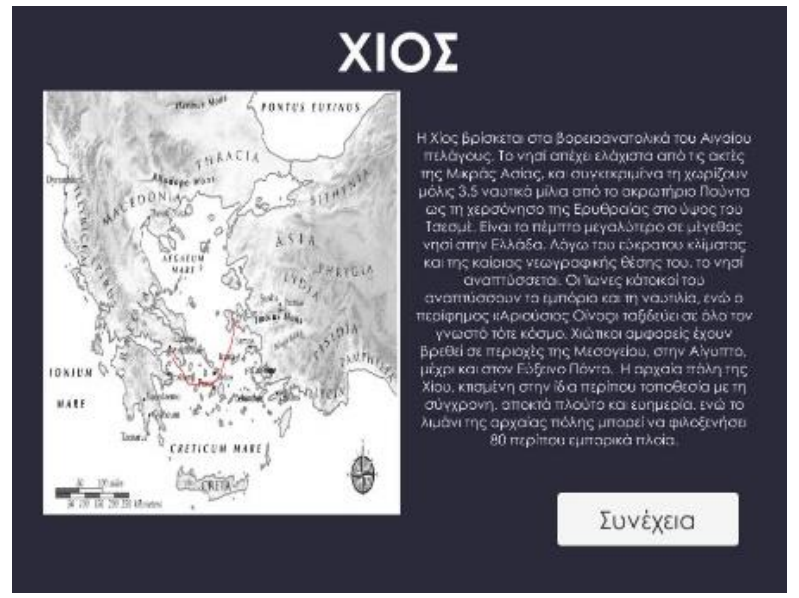

Figure 11. Information about the sea routes

When the player clicks the MEDWINET button he is ushered into the second part of the application, i.e. the virtual museum, which was based in previous work of the laboratory (Skamantzari \& Georgopoulos, 2016). Firstly, a simplified 3D model of the store was inserted to the game environment in order to place the 3D models later. The 3D models of the amphorae and the handles were inserted in .obj format. In order for the player to manipulate and rotate the objects it was necessary to create an empty game object which was placed in the centre of the 3D model and both of them were placed in the proper position in the virtual environment. Also the parameters of the main camera were adjusted including the ambience and the depth of field in order to provide a realistic view of the objects, positioned in their actual place. A script written in C\# language was added to every model in order to enable the manipulation and their rotation around their center of mass as well as the textual description when the visitor selects each exhibit. The rotation concerns only the 3D models of the amphorae.

At the beginning of the game some instructions are presented to the virtual visitor in order to guide him/her for exploring the virtual museum environment (Fig. 12).

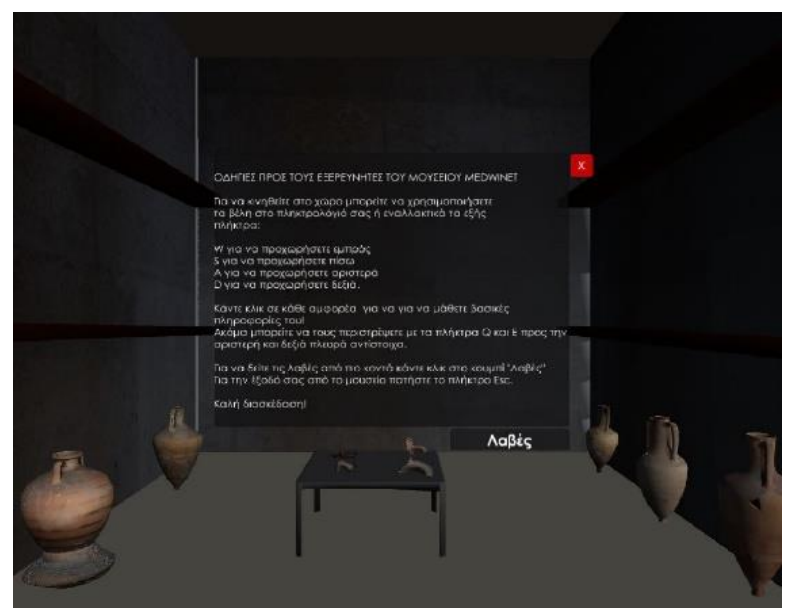

Figure 12. Instructions of the application

When the user clicks on the amphorae he/she is able to read information about the object and he can rotate it. A button was created in order to give the opportunity to the visitor to see more 
closely the 3D models of the handles placed on a table (Fig. 13). In this scene the player has the option to return in the amphorae scene with the click of B button.

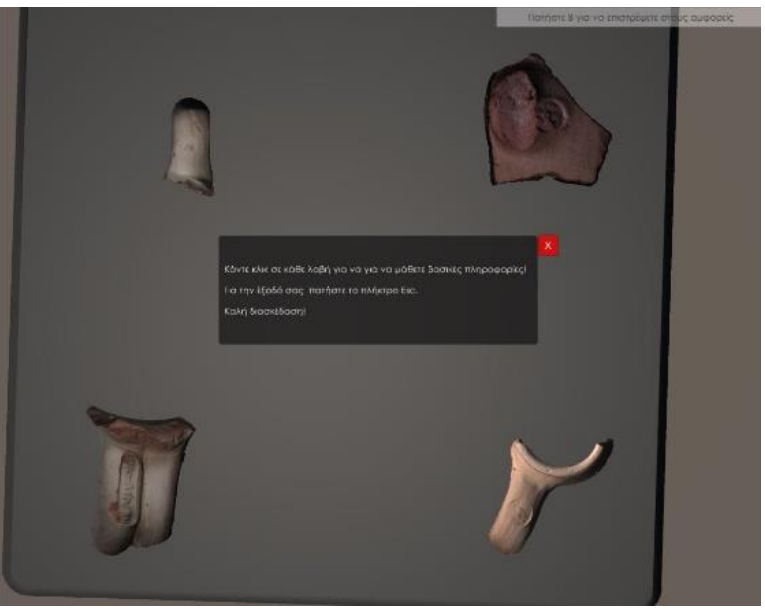

Figure 13. Virtual environment of the handles

In this way, the virtual visitor is offered the freedom of "wandering" around the amphorae museum at will and extract information about the objects and the general wine trade routes.

\section{EVALUATION}

A questionnaire was created, through the online survey tool Google Forms (Google forms, 2017), to evaluate the application by a potential audience. The evaluation form was completed by a random audience sample. Users who participated in the evaluation should first use the application and then answer the online questionnaire. Users experience is measured in terms of experience, knowledge gain, learning, ease of use, reliability of given information and realism. The questionnaire was grouped in two parts. The first one concerned user's general information (demographic data, knowledge background, use of apps, and visitation in museums). The second one focuses on the MEDWINET app and the experience gained through it with main focus points realism, reliability and ease of use.

A group of 15 users experienced MEDWINET and evaluated the application. $64 \%$ were women, and $40 \%$ of all the users in the age range of $19-30,27 \%$ of $31-45$ and $33 \%$ of $46-65$.

As far as computer knowledge is concerned all the users replied positively, and $27 \%$ of them use a technical device (pc, smartphone, or tablet) on a daily basis and $40 \%$ of them daily uses a digital application. According to the given answers, $46 \%$ of the users answered that they visit a museum once a year and all of them that are open in the idea to use a cultural application, similar to MEDWINET.

In the section of the questionnaire concerning the evaluation of MEDWINET, $100 \%$ of the users found the application realistic both as far as the virtual tour and also the 3D models is concerned. $60 \%$ characterized that the given information about the objects is very sufficient and $67 \%$ of them answered that the given map information was very sufficient (Fig. 14).

According to the survey, $53 \%$ of the users found the application easy to use, $13 \%$ extremely easy, in contrast with the $7 \%$ who found it not so easy (Fig. 14).
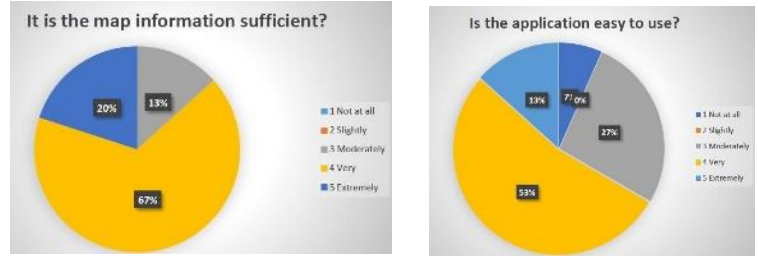

Figure 14. Pie charts concerning the sufficiency of given information and the easiness in use of MEDWINET

On the question if the application was enjoyable, $13 \%$ found the application extremely enjoyable, $80 \%$ of the users "moderately or very" enjoyed the application and only $1(7 \%)$ answered slightly. Finally, all the users considered that MEDWINET had an educational impact (67\% on the "very" level, $20 \%$ on "extremely" and 13\% on "moderately" (Fig. 15).

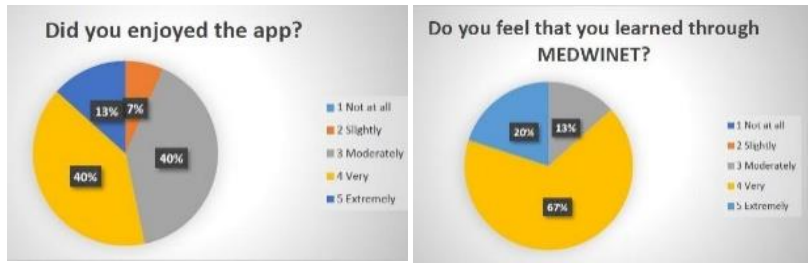

Figure 15. Pie charts presenting the entertaining and educational impact.

\section{CONCLUDING REMARKS AND FUTURE PERSPECTIVES}

This project is still in progress and many improvements have been already planned and are underway. Improvements which mainly concern the extended use of 3D models by the user in an interactive, educational and entertaining way. The primary intention of the archaeologists was to expose commercial amphorae and stamped handles to the public and to convey the history of trade in the Eastern part of Mediterranean Sea, focusing on five productive cities and during a period of more than 500 years.

In this contribution, the development of a virtual museum (MEDWINET) about the Stoa of Attalos has been designed and developed, firstly with the creation of 3D models of five amphorae and four stamped handles and secondly with the development of the virtual museum and edutainment application MEDWINET, in the Unity 3D personal edition game engine software. During this journey of creation, many issues occurred and were solved by using and testing new methodologies and data handling. New ideas have evolved to achieve a satisfactory result, with realistic and reliable data, for the Agora Museum in Athens and the potential visitors. The user at the final stage would have the ability of rotation of 3D models in any preferable scene view and would be able to interact though small-scale games and quizzes which mainly have educational character. The majority of improvements are focusing on the realism of the environment, the attraction of children, but also of experts or non- experts in the cultural heritage field. Museums, archaeologists and generally the cultural sector has the opportunity to use digital applications in order to provide historic events and exhibition to a wider range of visitors. 


\section{REFERENCES}

Dakari, K. 1996. The oldest of restorations. Mentor, issue 37, pp.90-163 (InGreek)

El-Hakim, S.F., MacDonald, G., Lapointe, J.F., Gonzo, L. and Jemtrud, M., 2006, November. On the Digital Reconstruction and Interactive Presentation of Heritage Sites through Time. In VAST (pp. 243-250).

Foley, B. \& Brendan P. Foley, M. C. H. D. P. K. T. A. T., 2012. Aspects of ancient Greek trade re - evaluated with amphora DNA evidence. Journal of Archaeological Science 39, pp. 389-398.

Gawlinski, L., 2014. The Athenian Agora : museum guide. Princeton, N.J: The American School of Classical Studies at Athens.

Glowanski, K., 2004. The Athenian Agora. $\Sigma \tau 0$ : P. O' Grady, $\varepsilon \pi \mu$. Meet the Philoshophers of Ancient Greece. Aldershot: Ashgate, p. Chapter 58.

Grace, V,., 1979. Amphoras and the ancient wine trade. ASCSA ed. Prisceton - New Jersey: American School of Classical Studies at Athens.

Hall, T., Ciolfi, L., Bannon, L., Fraser, M., Benford, S., Bowers, J., Greenhalgh, C., Hellström, S.O., Izadi, S., Schnädelbach, H. and Flintham, M., 2001, November. The visitor as virtual archaeologist: explorations in mixed reality technology to enhance educational and social interaction in the museum. In Proceedings of the 2001 conference on Virtual reality, archeology, and cultural heritage (pp. 91-96). ACM.

Hölscher, T., 2002. Klassische Archäologie. Grundwissen. Stuttgart: Wissenschaftliche Buchgesellschaft.

Hooker, J., 1980. Linear B: An Introduction. A' $\varepsilon \pi \mu$. Bristol: Bristol Classical Press.

Kersten, T. P., Tschirschwitz, F., and Deggim, S., 2017, DEVELOPMENT OF A VIRTUAL MUSEUM INCLUDING A 4D PRESENTATION OF BUILDING HISTORY IN VIRTUAL REALITY, Int. Arch. Photogramm. Remote Sens. Spatial Inf. Sci., XLII-2/W3, 361-367, doi: 10.5194/isprs-archives-XLII-2W3-361-2017

Kiourt, C., Koutsoudis, A., Markantonatou, S. and Pavlidis, G., 2016. THE 'SYNTHESIS'VIRTUAL MUSEUM Mediterranean Archaeology and Archaeometry, 16(5), pp.1-9.

Kiourt, C., Koutsoudis, A. and Pavlidis, G., 2016. DynaMus: a fully dynamic 3D virtual Museum framework. Journal of Cultural Heritage, 22, pp.984-991.

Lawall, M., 1999. Amphorae and Aegean trade: Structure and goals for future research. $\Sigma \tau 0$ : R. Docter \& E. Moorman, $\varepsilon \pi \mu$. Proccedings of the XV International Congress of Classicla Archaeology. Amsterdam: s.n., pp. 229-232.

Lepouras, G. and Vassilakis, C., 2004. Virtual museums for all: employing game technology for edutainment. Virtual reality, 8(2), pp.96-106.

Mauzy, G. A., 2006. Agora Excavations, 1931-2006: A Pictorial History. Athensl: American School of Classical Studies at Athens.
Skamantzari, M. and Georgopoulos, A., 2016, 3D VISUALIZATION FOR VIRTUAL MUSEUM DEVELOPMENT, Int. Arch. Photogramm. Remote Sens. Spatial Inf. Sci., XLI-B5, 961-968, doi: 10.5194/isprs-archives-XLI-B5961-2016

Sylaiou, S., Liarokapis, F., Kotsakis, K. and Patias, P., 2009. Virtual museums, a survey on methods and tools. Journal of Cultural Heritage, 10(4), pp.520-528.

Thompson, H. A., 1955. Activities in the Athenian Agora: 1954. Hesperia: The Journal of the American School of Classical Studies at Athens, January - March, 25(1), pp. 46-68.

Thompson, h. A., 1957. Activities in the Athenian Agora 1956. Hesperia, April - June, 27(2), pp. 99-107.

Thompson, H. A., 1959. Activities in the Athenian Agora: 1958. Hesperia The Journal of thw American School of Classical Studies at Athens, April - May, 28(1), pp. 91-108.

Whitbread, I. K., 1995. Greek Transport amphorae: a petrological and archaeological study. Athnes: British School at Athens.

Will, E. L., 1977. The ancient commercial amphora. Archaeology, Issue 30, pp. 264-278.

Stefanakis, M. 2012,Introduction to Classical Archeology. Basic Principles and Overview of Ancient Greek Art, 11th - 4th century BC Athens, Iamvlichos (In Greek).

Acropolis Museum, http://www.theacropolismuseum.gr/, (last accessed 06/2017)

Agisoft Photoscan, http://www.agisoft.com/, (last accessed 06/2017)

Bowens lights, http://www.bowens.co.uk/, (last accessed 06/2017)

DynaMus A Fully Dynamic 3D Virtual Museum Framework, http://dynamus.ceti.gr/tech.html, (last accessed 06/2017)

Google forms, https://www.google.com/forms/about/, (last accessed 06/2017)

Tech Virtual Museum, http://www.thetechvirtual.org/, (last accessed 04/2017)

Unity 3D, https://unity3d.com/, (last accessed 06/2017)

Valentino Garavani Museum, http://www.valentinogaravanimuseum.com/, (last accessed 04/2017) 